\title{
Stump appendicitis after laparoscopic appendectomy: case report
}

\section{Laparoskopik apendektomiden sonra güdük apandisit: Olgu sunumu}

\author{
Omaima BU-ALI, ${ }^{1}$ Mohamed AL-BASHIR, ${ }^{1}$ Hashim A SAMIR, ${ }^{2}$ Fikri M. ABU-ZIDAN ${ }^{1}$
}

\begin{abstract}
Stump appendicitis is a rare delayed complication of appendectomy. The delay in diagnosis is usually because of a prior history of appendectomy. We report a case of stump appendicitis diagnosed pre-operatively with a computerized tomography (CT) scan after laparoscopic appendectomy. An 18-year-old male presented with a one-week history of lower abdominal pain, nausea and vomiting. He had a history of laparoscopic appendectomy for acute appendicitis. Physical examination revealed tenderness and guarding in the lower abdomen. CT scan showed free pelvic fluid with a tubular structure of about $2.5 \mathrm{~cm}$ in length and $0.78 \mathrm{~cm}$ in diameter located posterior to the ileo-cecal junction. Laparoscopic exploration confirmed the findings. A residual appendiceal stump was found and dissected from the adhesion and removed. Histopathology showed a residual appendix with transmural neutrophilic infiltration associated with multifocal hemorrhagic necrosis. The postoperative period was uneventful. The diagnosis of stump appendicitis can be challenging. CT scan has proven to be a useful tool for the diagnosis of this rare condition.
\end{abstract}

Key Words: Appendicitis; CT scan; laparoscopy; stump.
Güdük apandisiti, nadir bir geç apendektomi komplikasyonudur. Tanıda gecikme olması, genellikle daha önceden bir apendektomi öyküsü bulunması yüzündendir. Biz, laparoskopik apendektomiden sonra bilgisayarlı tomografi (BT) ile ameliyat öncesi tanı konulan bir güdük apandisiti olgusu sunuyoruz. On sekiz yaşında bir erkek, bir haftalık bir alt karın ağrısı, bulantı ve kusma öyküsü ile başvurdu. Hastanın akut apandisit nedeniyle geçirilmiş bir laparoskopik apendektomi öyküsü vardı. Fiziksel incelemede alt karın bölgesinde hassasiyet, defans ve ağrı belirlendi. BT ile, ileoçekal bileşkenin arkasına yerleşimli yaklaşık $2,5 \mathrm{~cm}$ uzunluğunda ve $0,78 \mathrm{~cm}$ çapında tübüler bir yapıya sahip serbest pelvik sıvı bulunduğu saptandı. Laparoskopik inceleme, bulguları doğruladı. Rezidüel bir apandiks güdüğü bulundu, yapşıklıklardan ayrıldı ve rezeke edildi. Histopatoloji, multifokal hemorajik nekroz ile birlikte olan transmural nötrofilik infiltrasyona sahip rezidüel bir apendiks bulunduğunu gösterdi. Ameliyat sonrası sorun çıkmadı. Güdük apandisit tanısı zor olabilir. BT taraması, bu nadir durumun tanısına yönelik yararlı bir araç olduğunu kanıtlamıştır.

Anahtar Sözcükler: Apandisit; BT tarama; laparoskopi; güdük.
Incomplete appendectomy may predispose to the development of stump appendicitis. Stump appendicitis, the interval re-inflammation of the residual appendiceal tissue, is a rare complication of appendectomy. The diagnosis of stump appendicitis in a patient postappendectomy is challenging since it is rarely considered prospectively.

We report a case of stump appendicitis following laparoscopic appendectomy that was diagnosed pre-operatively with a computerized tomography (CT) scan.

\section{CASE REPORT}

An 18-year-old male presented with a one-week history of lower abdominal pain, nausea and vomiting followed by fever for one day. He had undergone laparoscopic appendectomy for acute appendicitis three months earlier with an uneventful postoperative course. Physical examination revealed tenderness and guarding in the lower abdomen. His white blood cell count was $9.8 \times 10^{9} / \mathrm{L}$.

The CT scan showed free pelvic fluid with a tubu- 


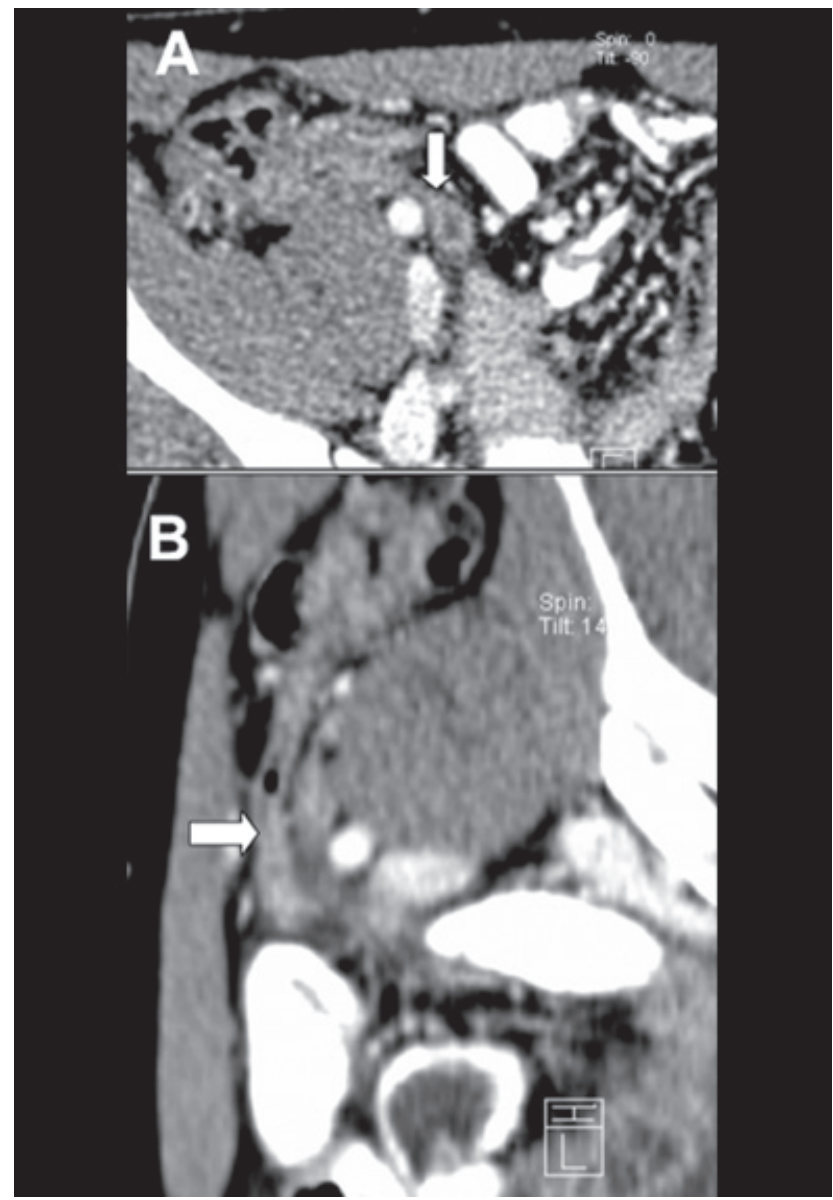

Fig. 1. Axial CT (A) shows the thickened and enhanced appendix stump (arrow) with peripheral mesenteric fat stranding. Curved multi-planar reconstruction (B) along the long axis of the appendix stump (arrow), measuring $2.5 \mathrm{~cm}$ in length, shows enhanced and inflamed distal segment. A small fluid collection is seen nearby. Note the presence of gas in the proximal part of the lumen of the appendix.

lar structure measuring $2.5 \mathrm{~cm}$ in length and $0.78 \mathrm{~cm}$ in diameter located posterior to the ileo-cecal junction (Fig. 1). Laparoscopic exploration revealed purulent fluid in the pelvis with multiple adhesions in the right iliac fossa. A residual appendiceal stump was found and dissected from the adhesion and removed. Histopathology showed a residual appendix with transmural neutrophilic infiltration associated with multifocal hemorrhagic necrosis. The postoperative period was uneventful. The patient was followed for nine months without any complaints.

\section{DISCUSSION}

The cause of stump appendicitis is incomplete removal of the appendix during the initial surgery. The re-inflammation of the residual appendiceal tissue is reported to occur as early as two months and as late as 50 years after the initial surgery. ${ }^{[1]}$
The diagnosis of stump appendicitis in a patient with previous appendectomy presents a diagnostic dilemma likely leading to delayed diagnosis and high perforation rate. ${ }^{[1]}$ It requires a high index of suspicion to be determined early. Ultrasonography and CT scan may be helpful in establishing the diagnosis prospectively. ${ }^{[2]}$ Interestingly, CT scan showed the presence of gas in the proximal part of the lumen of the appendix in our patient. About $15 \%$ of acute appendicitis cases will have gas in their lumen. ${ }^{[3]}$ There are a variety of possible explanations: the obstruction may have been limited to the distal part; the diagnosis may have been reached before the gas was absorbed; the gas may have been produced by bacteria distal to the obstruction; or the inflammation may have occurred without obstruction. ${ }^{[3]}$

The reports of stump appendicitis are rare and no relationship to a particular surgical technique can be made. It has been reported in patients following open appendectomy with stump ligation, ${ }^{[4]}$ open appendectomy with stump inversion ${ }^{[5]}$ and laparoscopic appendectomy. ${ }^{[1,2]}$ In laparoscopic appendectomy, the appendiceal stump is closed with an Endoloop or by stapling. In our case, the stump was closed with an Endoloop in the initial surgery and with staples in the second operation. There is no reported difference between the two surgical techniques except for the lower risk of postoperative intra-abdominal surgical site infection and need for readmission to hospital when staples are used. ${ }^{[6]}$

Regardless of the surgical technique used, identification of the appendiceal base by tracing the taenia coli down to the appendix is crucial in preventing such a complication. Stump appendicitis should be considered in the differential diagnosis of any patient with a previous history of appendectomy who presents with signs and symptoms of appendicitis. CT scan has proven to be a useful tool for the diagnosis of this rare condition.

\section{REFERENCES}

1. Liang MK, Lo HG, Marks JL. Stump appendicitis: a comprehensive review of literature. Am Surg 2006;72:162-6.

2. Shin LK, Halpern D, Weston SR, Meiner EM, Katz DS. Prospective CT diagnosis of stump appendicitis. AJR Am J Roentgenol 2005; 184:62-4.

3. Rettenbacher T, Hollerweger A, Macheiner P, Rettenbacher L, Frass R, Schneider B, et al. Presence or absence of gas in the appendix: additional criteria to rule out or confirm acute appendicitis--evaluation with US. Radiology 2000;214:183-7.

4. Thomas SE, Denning DA, Cummings MH. Delayed pathology of the appendiceal stump: a case report of stump appendicitis and review. Am Surg 1994;60:842-4.

5. Mangi AA, Berger DL. Stump appendicitis. Am Surg 2000;66:739-41.

6. Beldi G, Vorburger SA, Bruegger LE, Kocher T, Inderbitzin $\mathrm{D}$, Candinas D. Analysis of stapling versus endoloops in appendiceal stump closure. Br J Surg 2006;93:1390-3. 